\section{PARENTS' RESPONSE TO DISTANCE LEARNING POLICIES}

\author{
RESPON ORANGTUA TERHADAP \\ KEBIJAKAN PEMBELAJARAN JARAK \\ JAUH
}

Jurnal Pendidikan Luar Sekolah

http://kolokium.ppj.unp.ac.id/ Jurusan Pendidikan Luar Sekolah Fakultas Ilmu Pendidikan Universitas Negeri Padang

Sumatera Barat, Indonesia

Volume 8, Nomor 2, 2020 DOI: 10.24036/kolokium-pls.v8i2.399

Received 20 July 2020

Approved 17 August 2020

Published 30 October 2020

\author{
Sri Yunita Simanjuntak ${ }^{1}$, Kismartini ${ }^{2}$ \\ ${ }^{1}$ Universitas Diponegoro \\ ${ }^{2}$ Universitas Diponegoro \\ 3sriyunita864@gmail.com
}

\begin{abstract}
Efforts to prevent the transmission of the Covid-19 pandemic in primary schools are to issue a Distance Learning (PJJ) policy. The purpose of this study was to see the responses of parents to distance learning policies in North Sumatra. The research method is descriptive with a qualitative approach. The data collection technique is in the form of a questionnaire that is distributed online via google form. Respondents of this study were parents at the SD / MI and SMP / MTs levels in 6 districts / cities partnering the Tanoto Foundation in North Sumatra Province. The data analysis used is descriptive percentage using pivoting. The total respondents were 278 people who were selected by simple random. The conclusion of this study is that $99.64 \%$ of parents stated that children had implemented the PJJ program; 94\% of parents stated that they participated in guiding their children at home; $96 \%$ stated that they had been given instructions by the teacher in guiding the PJJ program; $65 \%$ of parents stated that they felt comfortable with PJJ activities.
\end{abstract}

Keywords: Parents, Participation, Distance Learning, Covid-19

\begin{abstract}
ABSTRAK
Upaya pencegahan penularan pandemik Covid-19 pada pendidikan dasar adalah dengan mengeluarkan kebijakan Pembelajaran Jarak Jauh (PJJ). Tujuan dari penelitian ini adalah untuk melihat respon orangtua terhadap kebijakan pembelajaran jarak jauh di Sumatera Utara. Metode penelitian yaitu deskriptif dengan pendekatan kualitatif. Teknik pengumpulan data berupa kuisioner yang dibagikan secara online melalui google form. Responden penelitian ini adalah orangtua di tingkat SD/MI dan SMP/MTs di 6 Kabupaten/Kota mitra Tanoto Foundation di Provinsi Sumatera Utara. Analisis data yang digunakan adalah deskriptif prosentase menggunakan pivoting. Total responden 278 orang yang dimbil secara acak sederhana. Kesimpulan dari penelitian ini adalah 99,64\% orangtua menyatakananaknyatelah melaksan program PJJ; 94\% orangtua menyatakan ikut berpartisipasi dalam membimbing anak dirumah; 96\% menyatakan telah diberikan petunjuk oleh guru dalam membimbing program PJJ; 65\% orangtua menyatakan merasa nyaman dengan kegiatan PJJ.
\end{abstract}

Kata Kunci: Orangtua, Partisipasi, Pembelajaran Jarak Jauh, Covid-19 


\section{PENDAHULUAN}

Proses pelaksanaan PJJ dirasa cukup baik untuk diberlakukan, mengingat bahwa sistem tersebut tetap memberikan ruang bagi pengajar dan peserta didik tetap berinteraksi dimanapun dan kapanpun. Sistem PJJ ini merupakan inovasi yang ditemukan terkait adanya keterbatasan dalam mengakses sistem pembelajaran maupun media pengajaran secara tatap muka (Gunawan, Ni Made Yeni Suranti, 2020). Sebenarnya sistem PJJ sudah lebih dulu diterapkan di Universitas Terbuka dan beberapa lembaga lainnya, hal ini karena lembaga atau universitas memiliki keterbatasan waktu, ruang dan mobilitas yang tinggi sehingga membuat sistem pembelajaran daring masih terus dilaksanakan dan masih berjalan. Namun sebelum adanya kegiatan yang membatasi perkumpulan masyarakat seperti saat pandemi ini tidak banyak sekolah-sekolah ataupun lembaga-lembaga yang menerapkannya karena kegiatan pembelajaran yang berlangsung secara tatap muka dirasa masih lebih memberikan kemudahan dan kenyamanan. Karena menurut Husamah dalam (Dian Ratu Ayu Uswatun Khasanah, Hascaryo Pramudibyanto, 2020) bahwa pandangan umum menunjukkan bahwa kegiatan pembelajaran secara tatap muka memberikan banyak kemudahan bagi pengajar maupun peserta didik, seperti faktor kedisplinan yang selalu di ajarkan dengan praktik langsung, memudahkan penguatan kepada murid, mempermudah proses penilaian dari hasil kerja murid kemudian menjadi wahana belajar dan praktik berbagai ilmu kepada muridmurid, Namun karen kondisi darurat Covid-19 yang masih melanda Indonesia, yang dilihat grafik dari persebarannya yang terus menerus naik dan menunjukkan tingkat penularan yang cukup tinggi, hal ini menuntut untuk setiap sekolah menerapkan suatu sistem pembelajaran yang tetap berlangsung namun tetap memperhatikan faktor keselamatan (Smith, A Wilder, 2020).

Dilihat dari kelebihan dari kegiatan pembelajaran secara tatap muka, maka ditemukan pula kelemahan yang juga dialami selama pengaplikasiannya disekolah. Menurut Husamah (Dian Ratu Ayu Uswatun Khasanah, Hascaryo Pramudibyanto, 2020) beberapa kelemahan yang dijumpa selama kegiatan tatap muka yaitu seperti kekakuan dalam belajar karena murid dituntut untuk belajar dengan cara mengajar, kemudian karena gaya belajar yang masih kaku sehingga terkadang dapat membuat murid kurang bisa menunjukkan variasi cara belajar mereka, kemudian metode belajar yang juga monoton. Maka pemerintah melalui kementrian Pendidikan dn Kebudayaan membuat Surat Edaran Kementrian Pendidikan dan Kebudayaan nomor 4 tahun 2020 tentang pelaksanaan kebijakan pendidikan dalam masa darutat penyebaran Cornavirus Disease (Covid-19). Isi dari salah satu kebijakannya adalah memberlakukan proses pembelajaran dari rumah melalui pembelajaran daring/ jarak jauh. Surat edaran ini ditujukan pada setiap sekolah baik dari tingkat PAUD hingga perguruan tinggi. Hal ini mengingat bahwa PJJ adalah opsi terbaik yang bisa diterapkan dalam sistem pendidikan di Indonesia kemudian dirasa cukup memberikan fleksibilitas dalam pelaksanaannya (Darmalaksana, 2020:2).

Metode PJJ ini dapat memberikan kemandirian belajar bagi setiap pelajar maupun pengajar dan mampu meningkatkan kreatifitasnya (S. R. Firman, 2020), (Simanjuntak, 2020). PJJ sangat identik dengan kegiatan digital, Sholichin (Laode Anhusadar, 2020) dan (Roida Pakpahan, 2020) (Nasution, 2020) dalam hal ini tidak terbatas pada teknologi internet saja namun juga segala perangkat pendukung digital tersebut sehingga keunggulan dari perangkat digital sangat berpengaruh terhadap kelancarannya. Dengan perangkat digital tersebut dalam hal ini khususnya murid disekolah dapat dengan mudah menerima pelajaran dimanapun dan kapanpun dan murid juga dapat dengan mudah mengajukan pertanyaan secara tidak lansung. 
Simmons dalam (Dian Ratu Ayu Uswatun Khasanah, Hascaryo Pramudibyanto, 2020) juga menyatakan dimasa ini sudah semakin banyak organisasi yang menerapkan kegiatan open learning sebagai metode atau sara penyampaian utama dalam kegiatan pelatihan dan lainnya. Namun dalam pengaplikasian kegiatannya banyak pihak yang merasa hal ini cukup mahal untuk diterapkan karena banyak hal yang berkenaan dengan kebutuhan digital yang juga harus terpenuhi, tapi hal ini dirasa cukup sepadan karena bentuk pembelajaran yang dilakukan secara online dianggap dapat menutup biaya transportasi karena harus datang kesekolah. Hal yang sama juga diteliti oleh (Purwanto, 2020) bahwa dengan mengurangi biaya transportasi guru ke sekolah juga meminimalisir tingkat stres yang dialami sat terjadi kemacetan.

Para murid disekolah dasar umum nya masih memiliki pengetahuan yang cukup sedikit mengenai teknologi dan penggunaannya, selain karena pembatasan penggunaan yang banyak dilakukan oleh orangtua kemudian selama ini murid-murid disekolah dasar kebanyakan menerima pelajaran secara langsung ataupun bertatap muka. Kemudian didukung dengan sistem motorik dan tingkat kecerdasan murid-murid di sekolah dasar yang masih terus berkembang, PJJ ini dirasa cukup efisien untuk diterapkan kepada murid-murid di sekolah dasar. Rasa ingin tahu mereka juga terus berkembang terhadap kemampuan digital dan komunikasi. Namun dalam penggunaan perangkat digital pada anak tersebut harus tetap dengan pengawasan orangtua, karena menurut penelitian (Hakam, M.T., Levani, Y. Utama, 2020) dari penggunaan perangkat digital kepada anak juga memiliki dampak negatif. Dampak negatifnya apabila penggunaan perangkat digital secara terus menerus untuk mendapatkan memenuhi kepuasan keingintahuannya dapat mengakibatkan ketidakpedulian terhadap lingkungan luar serta akan menimbulkan adiksi inernet. Dalam pengembangannya saat ini banyak ditemukan dan dikembangkan aplikasi online yang dikhususkan untuk bisa digunakan dalam memenuhi kebutuhan pembelajaran online, baik aplikasi untuk berbagi pesan maupun bertatap muka. Segala bentuk aplikasi sudah semakin banyak dikenalkan (Kusuma, J. W., 2020).

Para murid yang sedang melakukan PJJ diberikan materi oleh guru melalui media online seperti Whats App, zoom dan google classroom, (Idad Suhada, Tuti Kurniati, Ading Pramadi, 2020) (Hikmat, Hikmat and Hermawan, Endang and Aldim, 2020) dan (Muhdi, 2020) (Abidin Z., Rumansyah, 2020). Menurut (Kusuma, J. W., 2020) whatsapp digunakan dalam media pembelajaran sebagai wadah pembentukan grup belajar bagi murid-murid yang pesertanya adalah murid-murid dan guru, begitu juga grup yang berisikan para orangtua dan guru. Media ini digunakan untuk berbagi pertanyaan, pesan, tugas dan lain-lain Sedangkan untuk room merupakan platform tatap muka dalam pembelajaran sehingga murid dan guru dapat melangsungkan kegiatan belajar-mengajar pada platform tersebut. Kemudian menurut (Hanik, 2020) para murid juga dapat mengakses sumber pembelajaran, literasi dari berbagai media-media online maupun saluran televisi edukatif yang sekarang sudah banyak dikenal di Indonesia. Untuk akses buku pelajaran yang notabenenya tidak lagi bisa dikses maka dari segi penyediaan layananan kepustakaan juga diharapkan dapat tersedia. Menurut (Hanany, L. N. H., Robi'in, Sudirman E. Wardiyana, 2020) layanan kepustakaan sudah bisa dan tersedia pada beberapa perguruan tinggi mereka dapat mengakses informasi buku dari layanan kepustakaan perguruan tinggi. Namun tetap saja dalam proses keberlangsungan sistem PJJ pada sekolah dasar tersebut, tidak bisa terlepas dari bantuan bimbingan orangtua.

Peran Orangtua dirumah sangat diperlukan untuk membantu membimbing dan mengarahkan murid untuk mengikuti pelajaran yang diberikan oleh guru mereka. 
Ditambahlagi masih banyak murid khususnya sekolah dasar yang memiliki keterbatarsan dalam penerapan sistem PJJ tersebut. Selama masa PJJ guru tidak bisa langsung memantau bagaimana perkembangan pembelajaran yang diterima oleh murid sebagaimana saat proses pembelajaran langsung/offline dilakukan disekolah seperti dulunya. Dalam hal ini guru sebagai pengajar yang biasa memberikan pembelajaran melalui tatap muka, untuk sementara tidak lagi dapat membimbing murid langsung tapi harus secara jarak jauh Harding, et al, 2005 dalam (Rusdiana, A., Sulhan, M., Arifin, I.Z., Kamludin, 2020). Namun guru juga tetap dituntut untuk dapat menerapkan sistem pembelajaran daring, metode pembelajaran juga dituntut untuk diubah kedalam bentuk daring (Jamaluddin, dkk. 2020)). Karena media teknologi dan informasi menyediakan perangkt pembelajaran yang lebih menarik, komunikatif dan variatif, namun dari penelitian (Pribowo, 2020) menunjukkan masih banyak guru yang tidak mampu dalam mengoperasikan perangkat komputer dan media telekomunikasi lainnya.

Orangtua diperlukan untuk bisa selalu berkoordinasi dengan guru, memberikan masukan dan pertanyaan terkait pembelajaran yang sudah diterima dan yang akan didiberikan kepada murid. Agar pada saat murid telah merima pembelajaran yang diberikan, murid tersebut dapat benar-benar menerapkan sesuai dengan yang diberikan oleh guru. Menurut (Dewi, 2020) apabila orangtua tidak memiliki waktu dalam mengajar anak disaat orangtua sibuk bekerja disiang hari, orangtua dapat mendiskusikan waktu belajar yang tepat dengan guru pada saat mereka sudah selesai bekerja. Kemudian menurut (Hewi L., 2020) strategi dalam mendidik dan melihat perkembangan anak di era pandemi covid-19 adalah dengan melibatkan orangtua. Hal ini dirasa cukup efektif karena guru juga memiliki 2 tugas pokok yaitu memberikan perencanaan tugas dan memberikan penilaian murid. Kemudian bentuk strategi orangtua dalam membimbing anak selama dirumah bisa dengan mengarahkan anak bagaimana bentuk perilaku kesopanan dan tata krama yang bisa dicontoh, berdiskusi tentang aturan-aturan dirumah, memberikan cara yang mudah kepada anak terkait bagaimana metode pemecahan masalah yang berkaitan dengan pemeliharaan hubungan inter-personal dengan guru dan temannya, memberikan kesempatan anak untu mengerjakan secara mandiri tugas yang diberikan, dan selalu memberikan apresiasi kepada murid agar dapat mempertahankan kualitas belajarnya (Subarto, 2020).

Dari beberapa penelitian tentang proses berlangsungnya PJJ selama pandemi covid didapati banyak faktor penghambat dan faktor pendukung dari yang diterima murid dan orangtua dalam proses pelajaran. Dari kegiatan pembelajaran yang telah berjalan, kegiatan pembelajaran memang mengalami gangguan yang cukup besar, baik dari penerimaan pendidikan, menilaian, pembatalan penilaian dan lainnya (Aji, 2020). Pada faktor penghambat lainnya dalam hasil penelitian didapati bahwasanya murid kesulitan dalam mengakses pelajaran karena minimnya alat komunikasi, kemudian murid juga sangat sulit mengerti dan menerima pelajaran yang diberikan oleh guru melalui media online, kemudian tidak sedikit juga murid mengalami kebosanan dalam proses pembelajaran yang sedang berlangsung, bisa disebabkan karena ketidakpahaman murid sampai kepada kurangnya minat belajar murid karena tidak memiliki teman untuk berdiskusi tentang materi pelajaran yang mereka terima selama belajar dirumah.

Kegiatan pembelajaran online memiliki kelemahan utama yang paling sering terjadi seperti membutuhkan fasilitas internet yang memadai, sarana komuniasi yang memadai serta pemenuhan kuota internet. Orangtua sebagai penopang ekonomi banyak yang terimbas dari masa pandemi ini, banyak orangtua yang mengeluhkan terkait pemenuhan pembelian kuota 
untuk sekolah online anaknya kemudian orangtua juga tidak dapat membimbing anaknya karena sibuk bekerja untuk memenuhi kebutuhan dapur mereka (Surahman, dkk, 2020). Kemudian menurut (Laode Anhusadar, 2020) keterbatasan internet paling banyak dirasakan oleh masyarakat di daerah pelosok ataupun perkampungan yang tidak memiliki fasilitas internet yang memadai. Kemudian pada akses informasi dari buku pelajaran di sekolah khusus nya sekolah dasar, murid tidak bisa dengan mudah mencari referensi buku dari perpustakaan sekolah, karena layanan perpustakaan sekolah belum dapat mendukung kebutuhan akses buku bagi murid selama PJJ. Hal ini akan sangat memberikan kesulitan bagi muri-murid didaerah tersebut (Pratiwi E. Windhiyana, 2020).

Kemudian untuk faktor pendukungnya orangtua merasa lebih bisa memantau murid karena murid akan seharian melakukan proses belajar dari rumah (Sriwihajriyah, N., Ruskan, E. L., \& Ibrahim, 2020) dalam (Pratiwi E. Windhiyana, 2020), kemudian orangtua juga lebih leluasa melihat perkembangat pembelajaran yang diterima murid, kemudian orangtua juga dapat dengan mudah berkonsultasi dengan guru terkait masalah yang diterima oleh murid selama proses pembelajaran. (Dian Ratu Ayu Uswatun Khasanah, Hascaryo Pramudibyanto, 2020) menyatakan bahwa pembelajaran melalui jaringan memiliki potensi - potensi, antara lain kemudahan mengakses, kebermaknaan belajar dan peningkatan hasil belajar. Kemudian keuntungan yang bisa didapati dari kegiatan pembelajaran yang berlangsung secara online menurut (Pratiwi E. Windhiyana, 2020), (Murfi, 2020), (Satria, dkk, 2020)) (Sriwihajriyah, N., Ruskan, E. L., \& Ibrahim, 2020) (Wirani, 2020) dan (Zulaini N, dkk 2020) yaitu pembelajaran dilakukan secara mandiri dengan tingkat interaktif yang tinggi sehingga dapat meningkatkan daya kembang ingatan, menambahkan pengalaman belajar, baik dengan aiudio, video, teks dan animasi yang semua nya memberikan informasi dan kemudahan pencapaian bentuk penerapan kegiatan pembelajaran murid dan guru. Kemudian pembelajaran dan diskusi bisa diakses kapan dan dimanapun, bahan pelajaran juga tersimpan baik didalam komputer/gadget, murid atau guru yang rumahnya cukup jauh dapat menghemat waktu dan biaya transportasi.

PJJ memang memiliki tantangan yang cukup besar, selain karena guru tidak bisa bertatap langsung dengan murid sehingga tidak ada jaminan yang memastikan murid bisa benar-benr menerima, menyimak dan menguasai setiap pelajaran yang sedang berlangsung. Menurut Szpunar, Moulton dan Schacter dalam (S. R. R. Firman, 2AD) yang melakukan penelitian pada mahasiswa didapati mahasiswa lebih banyak menghayal pada pembelajaran online dari pada saat tatap muka, untuk itu Khan (S. R. R. Firman, 2AD)menyarankan agar nbentuk pembelajaran online jangan dilakukan dalam waktu yang lama karena konsentrasi tidak bisa selalu fokus kepada satu objek saja apalagi kegiatan belajar-mengajar berlangsung bisa lebih dari 1 jam.

Provinsi Sumatera Utara juga juga telah menerapkan kegiatan pembelajaran jarak jauh (PJJ). Hampir seluruh sekolah-sekolah dasar di Sumatera Utara sudah melaksanakan sistem pembelajaran online. Dari proses pelaksaan PJJ yang sudah berjalan, sangat ingin diketahui hal-hal apa saja yang ditemukan khususnya terhadap orangtua dalam proses pengaplikasian PJJ. Oleh karena itu penulis sangat tertarik untuk membuat tulisan yang bertujuan untuk mengetahui renspon orangtua terhadap Kebijakan Pembelajaran Jarak Jauh Di Sumatera Utara. Rumusan masalah dari penelitian ini adalah bagaimana respon orangtua terhadap Kebijakan Pembelajaran Jarak Jauh Di Sumatera Utara. 


\section{METODE}

Metode penelitian merupakan hal penting yang perlu diperhatikan. Penelitian ini merupakan jenis penelitian deskriptif dengan pendekatan kualitatif. Tujuan dari penelitian deskriptif adalah untuk memaparkan masalah-masalah yang ditemukan saat ini. Bisa disimpulkan bahwa penelitin deskriptif kualitatif adalah upaya untuk menemukan, mencatat dan mengklarifikasi kondisi yang ada sekarang. Penelitian dilakukan dimulai tanggal 14 - 30 Mei 2020, Penelitian dilaksanakan dengan mengirimkan form online berisi seperangkat pertanyaan yang akan diisi oleh responden kemudian dari jawaban yang diterima tersebut akan diulas masalah yang ditemukan serta dicari solusi maupun koherensinya dengan literatur yang diperoleh dari studi pustaka. Penelitian ini juga termasuk penelitian survey, yang mana penelitian survey menurut Yatim 2001 dalam (Dian Ratu Ayu Uswatun Khasanah, Hascaryo Pramudibyanto, 2020) mengandalkan teknik pengumpulan data berupa kuisioner, data survey dapat dikumpulkan dari populasi responden yang mengisi, untuk suatu hal yang bersifat nyata, hasil nya digunakan untuk kepentingan yang bersifat sementara atau terbatas waktu dan hasil survey digunakan untuk pemecahan masalah yang bersifat insidental. Responden yang mengisi koisioner tersebut berjumlah 278 orang yang merupakan orangtua murid di 118 sekolah mitra Tanoto Foundation. Orangtua tersebut tersebar di 6 Kabupaten/Kota yaitu Kabupaten Asahan, Kabupaten Karo, Kabupaten Deli Serdang, Kabupaten Barubara, Kota Pematangsiantar dan Kota Medan. Analisis dilakukan dengan melihat persebaran persentase dari setiap aspek pengukuran.

\section{PEMBAHASAN}

Tabel 1. RespondenOrangtua

\begin{tabular}{ccc}
\hline Kabupaten/ Kota & Responden Orangtua & Persentase \\
\hline Asahan & 5 & $1,80 \%$ \\
Batubara & 85 & $30,58 \%$ \\
Deli Serdang & 24 & $8,63 \%$ \\
Karo & 92 & $33,09 \%$ \\
Kota Medan & 41 & $14,75 \%$ \\
Kota Pematangsiantar & 31 & $11,15 \%$ \\
\hline Grand Total & 278 & $100 \%$ \\
\hline
\end{tabular}

Dari dari sebaran data yang telah diisi oleh responden guru yang telah diterima, responden orangtua paling banyak diisi oleh orangtua murid dari Kabupaten Karo yaitu sebanyak 92 orang, kemudian disusul oleh Kabupaten Batubara sebanyak 85 orang, Kota Medan 41 orang, Kota Pematangsiantar 31 orang, Kabupaten Deli Serdang 24 orang dan terakhir dari Kabupaten Asahan sebanyak 5 orang.

\section{Sarana Komunikasi yang Digunakan dalam Pelaksanaan Program PJJ}

Dari data yang telah diterima, media yang paling banyak digunakan dlam mengirim tugas adalah aplikasi berupa whatsapp, facebook, masanger, dan google hangout, sementara media yang digunakan dalam video conference berupa zoom, skeype, Dan soogle meet. Aplikasi tersebut memang paling banyak dan dirasa cukup efektif digunakan selama kegiatan online baik disektor pendidikan, ekomoni maupun lainnya. Hal ini menjadi alternatif terbaik yang bisa 
dipilih oleh setiap instansi dalam melaksanakan setiap program yang harus berlangsung. Sesuai dengan yang dikemukakan oleh (Suhada, dkk 2020) setiap murid yang belajar dengan metode PJJ diberikan tugas dan materi melalui media online berupa whatsapp, zoom, google classroom. Karena menurut Sholichin dalam (Laode Anhusadar, 2020) kegitan PJJ tidak terlepas dari penggunaaan perangkat digital. Dengan perangkat digital tersebut dalam hal ini khususnya murid disekolah dapat dengan mudah menerima pelajaran dimanapun dan kapanpun dan murid juga dapat dengan mudah mengajukan pertanyaan secara tidak lansung.

\section{Pelaksanaan Program PJJ}

Dari total responden orangtua sebanyak 287 orang atau sekitar 99,64\% menyatakan telah melaksan program PJJ. Hal ini dikarenakan sejak diberlakukannya pembatasan kegiatan sosial/perkumpulan selama masa pandemi yang diberlakukan mulai pertengahan bulan Maret lalu, memaksa sekolah juga turut untuk mengikuti kebijakan dan melaksanakan proses pembelajaran secara daring/online. Hal ini juga diharapkan untuk meminimalisir persebaran ataupun meminimalisir laju penularan virus pada anak-anak di sekolah dasar. Kesiapan dari orangtua dalam hal ini juga sangat diperlukan. Hal ini sesuai dengan isi SE PERMENDIKBUD nomor 4 tahun 2020 yang mengharuskan pelaksanaan kegiatan belajarmengajar tidak dilakukan secara tatap muka melainkan dilakukan dengan daring atau jarak jauh. Hal in diharapkan dapat menekan ataupun menghindari tingkat penularan pandemi Covid-19 yang bisa terjadi pada murid-murid di sekolah-sekolah baik itu sekolah tingkat PAUD sampai dengan perguruan tinggi. Hal ini juga sesuai dengan penelitian Simmons 2002 dalam (Khasanah, dkk 2020) yang menyatakan bahwa dimasa ini sudah semakin banyak organisasi yang menerapkan kegiatan open learning sebagai metode atau sara penyampaian utama dalam kegiatan pelatihan dan lainnya. Namun dalam pengaplikasian kegiatannya banyak pihak yang merasa hal ini cukup mahal untuk diterapkan karena banyak hal yang berkenaan dengan kebutuhan digital yang juga harus terpenuhi, tapi hal ini dirasa cukup sepadan karena bentuk pembelajaran yang dilakukan secara online dianggap dapat menutup biaya transportasi karena harus datang kesekolah. Kemudian menurut (Wirani, 2020) pembelajaran dan diskusi bisa diakses kapan dan dimanapun, bahan pelajaran juga tersimpan baik didalam komputer/gadget, murid atau guru yang rumahnya cukup jauh dapat menghemat waktu dan biaya transportasi.

\section{Peran Orangtua dalam Pelaksanaan Program PJJ}

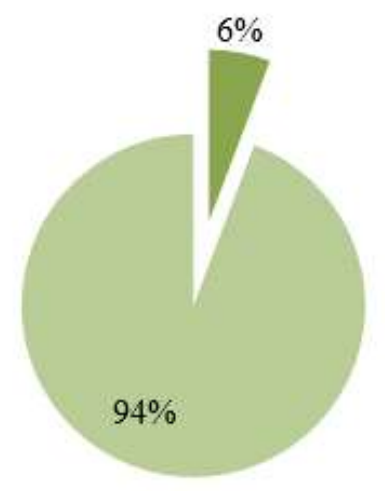

in Tidak

in $\mathrm{Ya}$

Grafik 1. Persentase Peran OrangtuadalamPelaksaan Program PJJ 
Dari data yang telah diterima dari responden didapati bahwa sekitar 94\% atau sebanyak 261 orang orangtua menyatakan ikut ambil bagian dalam membimbing murid selama proses belajar mengajar dirumah. Hal ini dikarenakan peran dari orangtua sangat besar dalam pelaksanaan Program PJJ ini, karena guru sebagaimana pendidik yang biasanya mengajar dan melihat pekembangan kemampuan belajar anak dikelas tidak bisa lagi memantau anak didiknya. Oleh karena itu orangtua diharapkan mampu memahami kondisi tersebut dan bisa lebih sabar dalam mendidik murid dirumah. Menurut penelitian dari (Hewi L., 2020) strategi dalam mendidik dan melihat perkembangan anak di era pandemi covid-19 adalah dengan melibatkan orangtua Dalam hal ini peran orangtua diperlukan untuk bisa selalu berkoordinasi dengan guru, memberikan masukan dan pertanyaan terkait pembelajaran yang sudah diterima dan yang akan didiberikan kepada murid. Agar pada saat murid telah merima pembelajaran yang diberikan, murid tersebut dapat benar-benar menerapkan sesuai dengan yang diberikan oleh guru. Namun dalam penggunaan perangkat digital pada anak tersebut harus tetap dengan pengawasan orangtua, hal ini sesuai dengan penelitian (Hakam, M.T., Levani, Y. Utama, 2020) dari penggunaan perangkat digital kepada anak juga memiliki dampak negatif. Dampak negatifnya apabila penggunaan perangkat digital secara terus menerus untuk mendapatkan memenuhi kepuasan keingintahuannya dapat mengakibatkan ketidakpedulian terhadap lingkungan luar serta akan menimbulkan adiksi inernet. Kemudian data tersebut juga menunjukkan $6 \%$ atau sekitar 16 orang menyatakan tidak ikut andil dalam membimbing anak. Hal ini dikarenakan beberapa orangtua sibuk bekerja dan tidak dapat membimbing anak dalam kegiatan pembelajaran dirumah. Menurut (Surahman, 2020) orangtua sebagai penopang ekonomi banyak yang terimbas dari masa pandemi ini, banyak orangtua yang juga harus bekerja dan tidak bisa membimbing anaknya dirumah.

\section{Petunjuk yang Diberikan Oleh Guru kepada Orangtua dalam Pelaksaan Program PJJ}

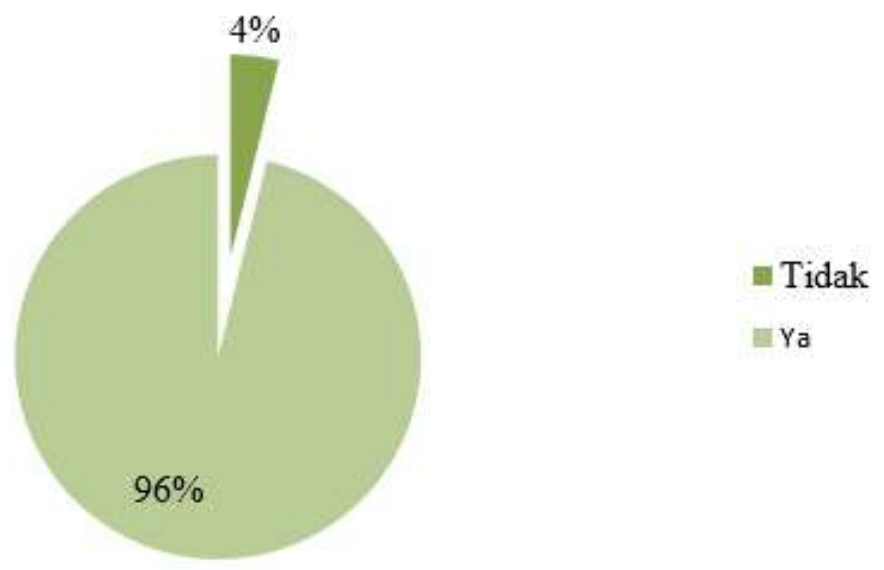

Grafik 2. PersentasePetunjuk Guru KepadaOrangtua

Dari data yang telah diterima 248 orang orangtua atau sebanyak 96\% menyatakan telah diberikan petunjuk oleh guru dalam membimbing program PJJ. Petunjuk dalam membimbing anak sangat penting diberikan oleh guru kepada orangtua, karena anak dianggap tidak selalu bisa dengan mudah mencerna pelajaran yang diberikan secara online/daring. Beda hal nya dengan saat guru bertemu dengan murid dikelas, guru bisa mengetahui bagaimana cara yang efektif dalam memberikan pemahaman terhadap setiap 
murid. Oleh karena itu, orangtua dianggap paling memahami karakter dari diri masingmasing anak mereka dirasa perlu diberikan beberapa panduan materi untuk orangtua bisa lebih mudah lagi menjelaskan terkait materi belajar yang telah diterima oleh murid. Dalam hal ini selaras dengan penelitian (Jamaluddin, 2020) yang menyatakan bahwa guru sebagai pengajar yang biasa memberikan pembelajaran melalui tatap muka, untuk sementara tidak lagi dapat membimbing murid langsung tapi harus secara jarak jauh. Namun guru juga tetap dituntut untuk dapat menerapkan sistem pembelajaran daring, kemudian dituntut juga untuk mengubah metode pembelajaran ke bentuk online. Kemudian data juga menunjukkan bahwa 10 orang atau sebanyak 4\% menyatakan tidak dapat dukungan oleh guru dalam program PJJ. Hal ini dikarenakan keterbatasan akses media telekomunikasi yang dialami oleh orangtua sehingga tidak bisa aktif berinteraksi dalam mengajukan pertayaan atau mengakses jawaban dari guru.

\section{Tingkat Kepuasan Orangtua dalam Pelaksanaan Program PJJ}

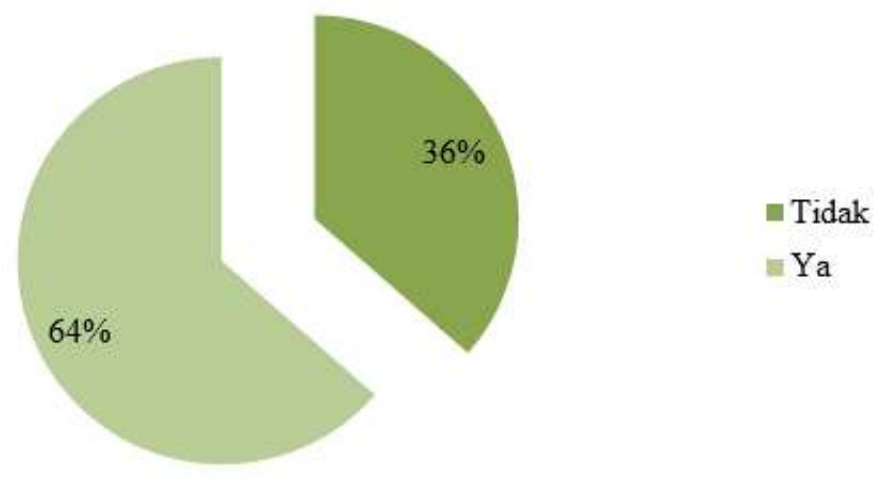

\section{Grafik 3. Persentase Tingkat Kepuasan Orangtua}

Dari data yang telah diterima sebanyak 65\% atau sekitar 176 responden orangtua merasa nyaman dalam pelaksanaan program PJJ. Orangtua yang merasa nyaman dalam kegiatan PJJ karena mereka lebih dapat memantau perkembangan anak, kemudian orangtua juga lebih bisa selalu berada didekat murid tanpa harus khawaitir dengan kegiatan murid selama diluar rumah atau pada saat melaksanakan pembelajaran diluar rumah. Kemudian tingkat kedekatan batin dari murid dan orangtua juga lebih dekat. Selain itu orangtua juga mampu menjadi tempat murid untuk bertukar pikiran ataupun berdiskusi tentang pembelajaran apa yang dirasa sulit diterima oleh murid dan dapat dipecahkan bersama-sama oleh murid dan orangtua. Hal ini selaras dengan penelitian yang dikemukakan oleh Sriwihajriyah dalam (Pratiwi E. Windhiyana, 2020) bahwa orangtua merasa lebih bisa memantau murid karena murid akan seharian melihat serta membimbing proses belajar dari rumah bersama dengan murid, Kemudian orangtua juga lebih leluasa melihat perkembangat pembelajaran yang diterima murid, kemudian orangtua juga dapat dengan mudah berkonsultasi dengan guru terkait masalah yang diterima oleh murid selama proses pembelajaran. Kemudian menurut penelitian Sriwihajriyah 2012 dalam (Pratiwi E. Windhiyana, 2020) orangtua juga dapat dengan mudah berkonsultasi dengan guru terkait masalah yang diterima oleh murid selama proses pembelajaran. Namun dari data juga ditunjukkan bahwa sebanyak 36\% atau sekitar 101 responden orangtua menyatakan rasa 
kurang puas dalam kegiatan pelaksaan program PJJ. Hal ini karena berbagai faktor kendala yang dialami oleh orangtua.

\section{Kendala yang Dihadapi Orangtua dalam Pelaksanaan Program PJJ}

Namun jika dilihat dari grafik 3 menunjukkan persentase 36\% atau sekitar 101 orang responden orangtua yang menyatakan ketidakpuasan terhadap pelaksanakan program PJJ. Alasan ketidakpuasan tersebut antara lain:

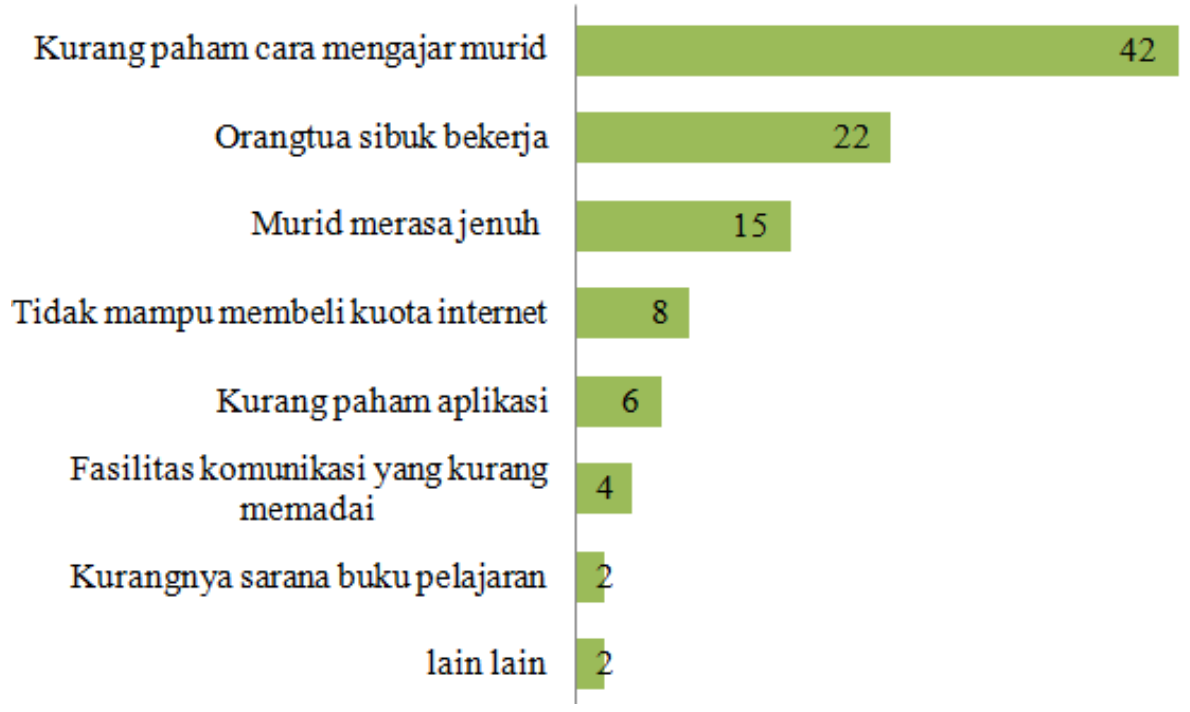

Grafik 4. Kendala yang Dihadapi Orangtua

Dari tabel dapat dilihat bahwa kendala paling yang dirasakan oleh orangtua adalah 42 orang menyatakan karena orangtua kurang paham bagaimana cara mengajar murid yang baik karena orangtua juga dituntut untuk bisa memahami semua mata pelajaran yang diberikan kepada murid. Kemudian alasan lain yaitu orangtua sibuk bekerja yaitu sebanyak 22 orang, hal ini juga menjadi kendala dalam pelaksanaan PJJ dirumah. Karena orangtua harus tetap mencari nafkah untuk memenuhi kebutuhan hidup sehari-hari. Kemudian 15 orang responden menyatakan bahwa murid merasa jenuh dalam proses pembelajaran dirumah, hal ini juga dikeluhkan oleh orangtua karena suasana belajar yang dirasa kurang menyenangkan oleh murid karena seyogyanya anak yang sedang tumbuh kembang memiliki rasa keingintahuan yang tinggi dan keinginan bersosial yang tinggi. Kemudian 8 orangtua lainnya menyatakan bahwa kesulitan dalam membeli kuota untuk bisa selalu terhubung dengan internet. Kemudian 6 orang responden lain menyatakan kurang memahami aplikasi karena orangtua memiliki keterbatasan dalam teknologi. Kemudian 4 orang responden lainnya menyatakan tidak memiliki fasilitas komunikasi dan 2 orang menyatakan kurangnya fasilitas belajar seperti buku. Kendala - kendala tersebut memang paling banyak didapati selama proses pelaksaan program PJJ. Hal ini selaras dengan penelitian dari (Pratiwi E. Windhiyana, 2020) yang menyatakan bahwa kegiatan pembelajaran online memiliki kelemahan utama yang paling sering terjadi seperti membutuhkan fasilitas internet yang memadai, sarana komuniasi yang memadai serta pemenuhan kuota internet. Kemudian menurut (Laode Anhusadar, 2020) keterbatasan internet paling banyak dirasakan oleh masyarakat di daerah pelosok 
ataupun perkampungan yang tidak memiliki fasilitas internet yang memadai. Hal ini akan sangat memberikan kesulitan bagi muri-murid didaerah tersebut.

\section{KESIMPULAN}

Sarana komunikasi yang paling banyak digunakan selama pelaksanaan program PJJ adalah whatsApp, Facebook, Masanger, dan Google Hangout, sementara media yang digunakan dalam video conference berupa Zoom, Skype dan Google Meet. Kemudian dari proses pelaksanaan program PJJ sebanyak 287 orang atau sekitar 99,64\% orangtua menyatakan anak mereka telah melaksanakan program PJJ. Kemudian dari tingkat partisipasi orangtua didapati bahwa sekitar 94\% atau sebanyak 261 orang orangtua menyatakan ikut ambil bagian dalam membimbing murid selama proses belajar mengajar dirumah. Kemudian dilihat dari petunjuk selama pelaksanaan program PJJ sebanyak 248 orang orangtua atau sekitar 96\% menyatakan telah diberikan petunjuk oleh guru dalam membimbing program PJJ. Kemudian dilihat dari tigkat kenyamanan orangtua dalam pelaksanaan PJJ sebanyak 65\% atau sekitar 176 responden orangtua merasa nyaman dalam pelaksanaan program PJJ. Namun kendala yang dialami oleh orangtua seperti kurang memahami cara mengajar murid, orangtua yang sibuk bekerja, murid merasa jenuh, tidak mampu membeli kuota, keterbatasan alat komunikasi, dan kurangnya sarana pembelajaran seperti buku.

\section{DAFTAR RUJUKAN}

Abidin Z., Rumansyah, K. A. (2020). Pembelajaran Online Berbasis Proyek Salah Satu Solusi Kegiatan Belajar Mengajar di Tengah pandemi Covid 19. Jurnal Ilmiah Profesi Pendidikan, 5(1), 68.

Aji, R. H. S. (2020). Dampak Covid-19 Pada Pendidikan di Indonesia: Sekolah, Keterampilan dan Proses Pembelajaran. Jurnal Sosial Dan Pembelajaran Syar'i, 7(5).

Dewi, W. A. F. (2020). Dampak Covid Terhadap Implementasi Pembelajaran daring di Sekolah dasar. Jurnal Ilmu Pendidikan, 2(1), 60.

Dian Ratu Ayu Uswatun Khasanah, Hascaryo Pramudibyanto, B. W. (2020). Pendidikan Dalam Masa Pandemi Covid-19. Jurnal Sinestesia, 10(1), 41-48.

Firman, S. R. (2020). Pembelajaran Online di Tengah Pandemi Covid-19. INDONESLAN JOURNAL OF EDUCATIONAL SCIENCE (IJES), 2(2), 81-89.

Firman, S. R. R. (2AD). Pembelajaran Online di Tengah Pandemi Covid-19. Indonesian Journal of Education Science (IJES), 2(86).

Gunawan, Ni Made Yeni Suranti, F. F. (2020). Variations of Models and Learning Platforms for Prospective Teachers During the COVID-19 Pandemic Period. Indonesian Journal of Teacher Education, 1(2), 61-70.

Hakam, M.T., Levani, Y. Utama, M. . (2020). Potensi Adiksi Penggunaan Internet Pada Remaja Indonesia Di Periode Awal Pandemi Covid-19. Jurnal Medical Hangtuah, 17(20), 111.

Hanany, L. N. H., Robi'in, Sudirman E. Wardiyana, Y. (2020). Pelayanan Perpustakaan Di Masa Pandemi Covid-19. Karya Tulis Ilmiah. UIN Sunan Gunung Djati Bandung.

Hanik, E. U. (2020). Self Directed Learning Berbasis Literasi Digital Pada Masa Pandemi Covid-19 di Madrasah Ibtidaiyah. Elementary Islamic Teacher Journal, 8(1), 205.

Hewi L., L. A. (2020). Strategi Pendidik Anak Usia Dini Era Covid-19 dalam Menumbuhkan 
Kemampuan Berfikir Logis. Jurnal Pendidikan Anak Usia Dini, 5(1), 166.

Hikmat, Hikmat and Hermawan, Endang and Aldim. (2020). Efektivitas pembelajaran daring selama masa pandemi Covid-19: Sebuah survey online. Digital Library UIN Sunan Gunung Djati.

Idad Suhada, Tuti Kurniati, Ading Pramadi, M. L. (2020). Pembelajaran daring berbasis Google Classroom mahasiswa pendidikan biologi pada masa wabah Covid-19. Digital Library UIN Sunan Gunung Djati, 1-10.

Jamaluddin, D. (2020). Pembelajaran Daring Masa Pandemik Covid-19 Pada Calon Guru: Hambatan, Solusi, Proyeksi. Karya Tulis Imiah LPPK UIN Sunan Gunung Djati Bandung.

Kusuma, J. W., H. (2020). Perbandingan Hasil Belajar Matematika dengan Menggunakan Platform Whatsapp Grup dan Webinar Zoom dalam Pembelajaran Jarak Jauh Pada Masa Pandemik Covid-19. Jurnal Imiah Pendidikan Matematika, 5(1).

Laode Anhusadar. (2020). Persepsi Mahasiswa PIAUD terhadap Kuliah Online di Masa Pandemi Covid 19. Journal of Islamic Early Childhood Education, 3(1), 44-58.

Muhdi, N. (2020). Keefektivan Kebijakan E-Learning berbasis Sosial Media pada PAUD di Masa Pandemi Covid-19. Jurnal Obsesi: Jurnal Pendidikan Anak Usia Dini., 5(1), 225.

Murfi, A. (2020). Kepemimpinan Sekolah dalam Situasi Krisis Covid-19 di Indonesia. Jurnal Manajemen Pendidikan Islam, 5(1), 153.

Nasution, M. R. (2020). Covid-19 Tidak menjadi hambatan Pendidikan di Indonesia?, 6.

Pratiwi E. Windhiyana. (2020). Dampak Covid Terhadap Kegiatan Pembelajaran Online di Sebuah perguruan Tinggi Kristen di Indonesia. Jurnal Perspektif Ilmu Pendidikan, 34(1), 7.

Pribowo, F. S. . (2020). Persepsi Guru SD Muhammadiyah Terhadap Penggunaan Gawai dalam Pembelajaran di Kelas. In Proceding (p. 129).

Purwanto, A. (2020). Studi Ekspolrasi Dampak Work From Home (WFH) Terhadap Kinerja Guru Selama Pandemi Covid-19. Jurnal Of Education, Psicology and Conceling, 2(1), 92.

Roida Pakpahan, Y. F. (2020). Analisa Pemanfaatan Teknologi Informasi dalam Pembelajaran Jarak Jauh di Tengah Pandemi Virus CORONA COVID-19. JIS AMAR (Journal of Information System, Applied, Management, Accounting and Research), 4(2), 30-36.

Rusdiana, A., Sulhan, M., Arifin, I.Z., Kamludin, U. . (2020). Penerapan Model POE2WE Berbasis Blended Larning Goofle Classroom Pada Pembelajaran Masa WFH Pandemic Covid-19. Karya Tulis Ilmia. UIN Sunan Gunung Djati Bandung.

Satria, L. (2020). Optimalisasi Bimbingan Online Dalam Upaya Mencegah Penyebaran Virus Covid-19 (pada Fakultas Dakwa dan Komunikasi, UIN SGD Bandung). Karya Tulis Ilmiah. UIN Sunan Gunung Djati Bandung.

Simanjuntak, S. Y. K. (2020). Respon Pendidikan Dasar Terhadap Kebijakan Pembelajaran Jarak Jauh Selama Pandemi Covid-19 di Jawa Tengah. Jurnal Ilmu Wahana. Jurnal Ilmu Wahana, 6(3), 308-316.

Smith, A Wilder, D. O. F. (2020). Isolation, quarantine, social distancing and community containment: pivotal role for old-style public health measures in the novel coronavirus (2019-nCoV) outbreak. Journal of Travel Medicine.

Sriwihajriyah, N., Ruskan, E. L., \& Ibrahim, A. (2020). Sistem pembelajaran dengan elearning untuk persiapan ujian nasional pada SMA Pusri Palembang. Jurnal Sistem Informasi, 4(1), 449.

Subarto. (2020). Momentum Keluarga Mengembangkan Kemampuan Belajar Peserta Didik 
Parents' Response to Distance Learning Policies in North Sumatra

Di Tengah Wabah Pandemi Covid-19. ADALAH: BULETIN HUKUM \& KEADILAN, 4(1), 16.

Surahman. (2020). Menumbuhkan Motivasi Bekerja dan Cara Mengatur Keuangan Selama Masa PSBB Covid-19. Jurnal Abdi Masyarakat Humanis, 1 (2), 137.

Wirani, N. (2020). Pentingnya Penggunaan Model Pembelajaran Berbasis Web Untuk Mencegah Penyebaran Covid-19, 23.

Zulaini N, dkk. (2020). Pembelajaran Bahasa Arab untuk Madrasah Ibtidaiyah Pada Masa Wabah Covid-19. Journal of Education, 3(1), 53. 